\title{
Local Government Policy to Realize Integrity and Governance to Tackle Corruption Crimes: A Study of Recruitment Patterns of Regional Institution Officers in Batang Regency and Pekalongan City
}

\author{
Pujiyono $^{1}$, Rahmi Dwi Sutanti ${ }^{2}$, Aista Wisnu Putra ${ }^{3}$, Nissa Dayu Suryaningsih $^{4}$ \\ \{pujiyono@lecturer.undip.ac.id ${ }^{1}$ \} \\ Universitas Diponegoro, Indonesia ${ }^{1,2,3,4}$
}

\begin{abstract}
The object of the regional head's policies varies according to the region's needs and the objectives of the regional government. The object of the regional head is affected by the issuance of the regional head's policy. This study aims to describe regional head policies in realizing governmental apparatus with integrity to prevent corruption crimes by studying recruitment patterns of regional agency officials. Therefore, this paper aims to identify and analyze the policies taken by the Regional Heads in realizing government officials with integrity to tackle corruption by knowing and analyzing the pattern of recruitment of regional agency officials as an effort to tackle corruption. According to this juridical sociological research with comparative approach, some policies in Batang Regency and Pekalongan City have some problems. The results showed that the policy of the Regional Head in realizing government apparatus with integrity as an effort to tackle criminal acts of corruption. It can take the form of policies in education that require anticorruption education for prospective employees of regional agencies. It is reflected in Governor Regulation No. 10 of 2019 concerning the implementation of Anti-Corruption Education in Central Java.
\end{abstract}

Keywords: Political Appointment, Governance, Integrity, Corruption, Indonesia

\section{Introduction}

Government apparatus with integrity is one of the critical things for regional agency officials in carrying out their duties, including the importance of being owned by Regional Heads and Regional Agency Officials. However, portraits of regional heads and regional agency officials who have committed acts of corruption are not rare in Indonesia. Data shows, as long as the KPK was established from 2002 to 2019, there were 21 Governors and 122 Regional Heads (Mayor/Regent and Deputy) who committed criminal acts of corruption. Meanwhile, 230 Echelon I, II, and III officials committed criminal acts of corruption [1].

One of the portraits of the criminal act of corruption committed by the regional head in Central Java is the case that befell the inactive Klaten Regent, Sri Hartini, in 2016. Sri Hartini was sentenced to 11 years in prison and a fine of 900 million rupiahs by the Corruption Criminal Court (Tipikor) Semarang based on bribery and gratification. The former Klaten Regent received gratuities and a bribe of Rp. 12,800,000,000 [2]. Then the Inactive Kudus Regent, M. Tamzil, was also convicted of a corruption case related to the sale and purchase of positions. 
Tamzil was found guilty by the court for receiving gratuities and bribes from the Acting Task Force (PIt.) Secretary of the Kudus Regency Revenue, Financial Management and Asset Service (DPPKAD) named Akhmad Shofian. Bribes were given so that Akhmad Shofian and his wife Rini Kartika could get a new position at the echelon III level. The corruption case committed by two Regional Heads, apart from contradicting the ASN Law, Sri Hartini and M. Tamzil, also injured the vision/tagline of the Central Java Governor, Ganjar Pranowo, namely "Mboten Korupsi lan Mboten Ngapusi" [3].

This phenomenon encourages curiosity about the policies possessed by regional heads in realizing government apparatus with integrity and the pattern of recruitment of officials from regional agencies to tackle corruption. It is the background of the research entitled "Local Government Policies in Realizing Governmental Apparatus with Integrity as Efforts to Prevent Corruption Crimes (Study of Recruitment Patterns of Regional Agency Officials in Batang Regency and Pekalongan City)". Therefore, this paper aims to identify and analyze the policies taken by the Regional Heads in realizing government officials with integrity as an effort to tackle corruption. It was knowing and analyzing the pattern of recruitment of regional agency officials to tackle corruption.

\section{Research Question}

Based on introduction above, several research questions have been formulated. First, how the legal policy of regional agency officials in Pekalongan City. Second, how the legal policy of Regional Agency Officials in Batang Regency.

\section{Theoretical Framework}

\subsection{Local Government Policy}

Policy terminology in this paper is the action of government officials in carrying out government duties according to their authority in the form of legal instruments. Local government policy in this paper is refer to Indonesian local government leader in City or Regency. Included in the legal form of regional head policies are mayor regulation, mayor decree and all regulation issued by local governmental institutions.

\subsection{Integrity of Governmental Apparatus}

Integrity come form latin language integer which mean complete or intact. Integrity in practice defined as consistency between thoughts, feelings, and actions against applicable values or rules. Govermental apparatus integrity which mean in integrity owned by person who serve and work to government. Government apparatus obliged to carry out the function of service to the community (civil services). Permatasari [4] and Kirana [5] suggested to person to work with integrity to have significant positive influence in work performance. This meant that integrity is very important in person work including governmental apparatus who served community in public service. 


\subsection{Corruption Crimes Prevention}

Corruption crimes in Indonesia regulated law number 31 of 1999 in conjunction with law number 20 of 2002. Overall, corruption is a crime that is detrimental to state finances. In Indonesia prevention of corruption crimes divided into three types of prevention. The types of prevention are education, law enforcement, and system improvement.

\subsection{Recruitment Patterns of Regional Government Apparatus in Indonesia}

Recruitment defined as activities to find people needed to do something. Pattern of indonesian regional government apparatus recruitment affected by law and policy that ruled government apparatus. The first pattern in 2014 imposed a legal basis that high-ranking regional officials were directly elected by the regional head (Governor, Mayor, or Regent). After that, laws and implementing regulations governing open selection were issued, namely First Article 108, Article 109, Article 110, Article 116, Article 117, Article 118 and Article 120 of Law Number 5 of 2014 concerning State Civil Apparatus. Second, Article 205, Article 208, Article 233, Article 234 and Article 235 of Law no. 23 of 2014 concerning Regional Government. Third Law No. 10 of 2015 Article 71, concerning the second amendment to Law No. 1 of 2015 concerning the stipulation of Perpu No. 1 of 2014 concerning the Election of Governors, Regents and Mayors into Law. Fourth, Regulation of the Minister of Utilization of the State Apparatus and Bureaucratic Reform (PANRB) Number 13 of 2014 concerning Procedures for Filling the Position of Primary High Leaders through Open Selection in Government Agencies.

\section{Methodology}

This research used juridical sociological method with comparative approach. Juridicial sociological method is a suitable method for this research, because the object under study is the law that applies in a particular area and its legal applications. Each region certainly has different legal policies and implementations regarding the selection of regional agency officials.

Comparative approach is used in this research to analyze to analyze the differences of the legal policies for selecting regional agency officials in Batang Regency and Pekalongan City. Each region each region has a different legal policy that is adapted to the characteristics and needs of the region. The implementation of legal policies in each region also has different problems and advantages according to the social, political, and cultural dynamics adopted by the community.

\section{$5 \quad$ Results and Discussion}

\subsection{Good Governance and Legal Basis in Integrity of Regional Government Apparatus}

A government with integrity is closely related to governance, namely, a mechanism for managing economic and social resources that involve the influence of the state sector and the non-government sector in a collective activity [6]. Meanwhile, good governance is 
etymologically translated into good management or good governance [7]. According to Toha [8], good governance is concluded as open, clean, authoritative, transparent, and responsible.

The characteristics of Good Governance, according to the United Nations Development Program [9], are:

a. Participatory, good governance is a government with an active participation system from the party being governed (people/society).

b. Transparent, all information that the public should know can be accessed easily.

c. Accountable, every government action is accountable in accordance with the initial planning.

d. Effective, government action should have a good effect and be effective for the community.

e. Equitable, the government views every citizen fairly and equally in government.

f. Promoting the rule of law, promoting that the law is the commander who leads the country, not just power.

As for public policy based on the Big Indonesian Dictionary, a policy is a series of concepts and principles that form the outline and basis of a plan to implement a job in achieving goals or objectives. Etymologically, the term policy comes from Greek, namely, polis, which means "city-state", and Sanskrit is called pur, which means "city", and in Latin, it is called politia, which means state [10].

Dunn [11] defining Public Policy is a guideline that contains values and norms that have the authority to support government actions in its jurisdiction. Based on this understanding, it can be understood that public policy is a direction of action taken by the government which has the authority to achieve specific goals and overcomes a problem in which there are obstacles and opportunities to create a good impact on the Public.

Arief [12] revealed the development of criminal objectives, namely as follows:

a. Seen from the aspect of protection against crime, the goal of crime is the prevention of crime.

b. Viewed from the aspect of protection of the perpetrator, the purpose of the crime is to improve the perpetrator (change behavior).

c. Viewed from the Protection against Abuse of Sanctions/Reactions, the purpose of the crime is to regulate/limit the arbitrariness of the authorities and citizens of society.

d. Viewed from the aspect of protection of the disturbed balance of interests/values, the purpose of the crime is to maintain/restore the balance of society.

The authority of a regional head is often referred to as a policy issued by a regional head with a specific purpose to carry out regional government functions. It can be concluded that the form of legal policy is in the form of regulations where the regional head interferes, namely Regional Regulations, Regional Head Regulations, Regional Head Decrees, and other policies required by regions and the community in accordance with the provisions of statutory regulations.

The object of the regional head's policies varies according to the region's needs and the objectives of the regional government. The object of the regional head is affected by the issuance of the regional head's policy. One example of the regional head's policy object is the regional government apparatus as the party led by the regional head in carrying out the wheels of regional government.

Regional head policies towards regional apparatus must also have specific objectives. The policy objectives for these officials must also be in line with the objectives of the regional government. One of the regional head's policy objectives towards regional government officials is to improve the capacity of the regional government apparatus for the better. These policies 
are included in the class of policies with the aim of increasing the capacity of the human resources (HR) of the government. One of the crucial capacities to be improved for state apparatus in the regions is increasing the capacity of human resources to become more integrity.

Therefore, it is crucial as a regional head to make public policies in realizing government apparatus with integrity as an effort to tackle corruption. Based on the research that has been done, several regional policies in the context of realizing government apparatus with integrity as an effort to tackle the criminal act of corruption, namely Governor Regulation No. 10 of 2019 concerning the implementation of Anti-Corruption Education in Central Java.

The regulation contains Anti-Corruption Education in the State Civil Apparatus (ASN) implemented in the Training Program (Technical Training, Training for Functional Positions, Managerial Training, Training for Regional Apparatus Leaders, Basic Training for Prospective Civil Servants (Latsar CPNS), and other Development Training in accordance with the provisions of the legislation). Anti-Corruption Education materials are included in every ASN Education training curriculum.

As for several policies that the government has carried out in efforts to combat corruption crimes related to the selection of high-ranking regional officials, among others:

a. Law No. 5 of 2014 concerning State Civil Servants, among other things, mandates that filling high leadership positions be carried out openly and competitively.

b. Law No. 23 of 2014 concerning Regional Government as amended several times, most recently by Law No. 9 of 2015 concerning the Second Amendment to Law No. 23 of 2014 concerning Regional Government.

c. Government Regulation No. 11 of 2017 concerning Management of Civil Servants as amended by Government Regulation No. 17 of 2020 concerning Amendments to Government Regulation No. 11 of 2017 concerning Management of Civil Servants.

d. Government Regulation No. 18 of 2016 concerning Regional Apparatus as amended by Government Regulation No. 72 of 2019 concerning Amendments to Government Regulation No. 18 of 2016 concerning Regional Apparatus;

e. Regulation of the Minister of State Apparatus Empowerment and Bureaucratic Reform of the Republic of Indonesia No. 15 of 2019 concerning Filling of High Leadership Positions Openly and Competitively in Government Agencies.

f. Circular of the Minister of Empowerment of State Civil Servants and Bureaucratic Reform No. 52 of 2020 concerning the Implementation of Open and Competitive Filling of High Leadership Positions in Government Agencies in Public Health Emergency Conditions of Corona Virus Disease 2019 (Covid-19).

\subsection{Legal Government Policy of Recruitment Local Government Apparatus in Pekalongan City}

As for what has explicitly been issued by the regional head (Pekalongan Mayor) in the administrative area of Pekalongan City, Central Java Province, among others ${ }^{1}$ :

a. Pekalongan City Regional Regulation No. 5 of 2016 concerning the Formation and Composition of Regional Apparatus for the City of Pekalongan as amended by Regional Regulation of the City of Pekalongan No. 3 of 2020 concerning Amendments to the Regional Regulation of the City of Pekalongan No. 5 of 2016 concerning the Formation and Composition of Regional Apparatus for the City of Pekalongan.

\footnotetext{
${ }^{1}$ Interview with Miji Rustanti, Head Staff of the Pekalongan City Civil Service Agency, 26 November 2020.
} 
b. Pekalongan Mayor Regulation No. 102 of 2016 concerning Duties. Functions and Job Descriptions of Structural Positions for Regional Apparatus of Pekalongan City.

c. Decree of the Mayor of Pekalongan No. 800/830 of 2019 concerning Competency Standards for Primary High Leaders in the Pekalongan City Government.

The implementation of the policy is carried out in several activities, including:

a. Organizing the Pekalongan Municipal Government ASN Work Assessment Team Meeting, where the results become the Mayor's consideration for the inauguration of structural officials' transfer/promotion.

b. Pekalongan City Government ASN Competency Assessment/Test

c. The implementation of open selection and rotation selection for the Filling of the Positions of the Senior High Leaders of the Pekalongan City Government.

As for the policies/legal basis/legal rules of the Mayor of Pekalongan in the recruitment of officials from regional agencies, namely:

a. Decree of the Mayor of Pekalongan No. 800/803 of 2020 concerning the Establishment of an Open and Competitive Selection Committee in the Pekalongan City Government in 2020.

b. Decree of the Mayor of Pekalongan No. 800/804 of 2020 concerning the Formation of a Steering Team, Secretariat Team, and Management Team for Open and Competitive Selection Activities of Filling Primary High Leaders in Pekalongan City Government in 2020.

The pattern of recruitment of regional agency officials as an effort to tackle corruption is reflected in the Implementation and Method of Open Selection/Rotation of Primary High Position, namely:

a. Selection Announcement Stage Announcement of Selection is disseminated through print and online media, accessed by people in the province of Central Java for 5 (five) calendar days.

b. Administrative Selection Stage It aims to determine the selection participants who meet the administrative requirements and are entitled to participate in the next selection stage.

c. Competency Test Stage

It aims to filter participants based on their ability from a managerial perspective. Rating Weight: $25 \%$.

d. Track Record Tracing Stage

It aims to obtain more information about the qualifications and qualities of candidates. It is done by tracing the track record information of participants from their work environment. Rating Weight: $20 \%$.

e. Written Idea Test and Interview Phase

It aims to filter participants based on field competencies and assess the ability of participants to understand the socio-cultural conditions in Pekalongan City through writing papers and interviews. The weighted assessment is $20 \%$ for the Written Idea Test and $35 \%$ for the interview.

f. Stage of Announcement and Submission of Selection Results to the Civil Service Officer (PPK), namely the Mayor of Pekalongan. 


\subsection{Legal Government Policy of Recruitment Local Government Apparatus in Batang Regency}

The administrative area of the Batang Regency government has the same organic legal basis as the selection in Pekalongan. As for those specifically regulating in the Batang Regency area, namely ${ }^{2}$ :

a. Announcement No. 01/Pansel.JPTP.Sekda.BTG/XI/2020

b. Announcement No. 02/Pansel.JPTP.Sekda.BTG/XI/2020

c. Announcement No. 03/Pansel.JPTP.Sekda.BTG/XI/2020

d. Announcement No. 04/Pansel.JPTP.Sekda.BTG/XI/2020

Selection is carried out by forming a selection committee consisting of high-ranking regional government officials, inspectorates, and elements outside the government, such as academics and community leaders who are considered influential.

The selection results determine the three-best people with the highest score based on the selection committee's assessment. The best names are submitted to the Regional Head (Governor/Regent/Mayor) to be elected. Regional Heads are free to choose who is elected from the names proposed, not from the best score or first rank. Other considerations for the regional head to choose other than rank are the alignment of the candidate's program targets with the regional head's vision and mission, manners, etc.

As for the obstacles that arise in recruiting local agency officials, namely applicants lacking/not meeting the quota, the solution is that the Mayor of Pekalongan City issues a Mayor's circular for officials who meet the requirements to participate in applying for the selection.

\section{Conclusion}

The policy of the Regional Head in realizing government apparatus with integrity as an effort to tackle criminal acts of corruption. It can take the form of policies in education that require anti-corruption education for prospective employees of regional agencies. It is reflected in Governor Regulation No. 10 of 2019 concerning the implementation of Anti-Corruption Education in Central Java.

The pattern of recruitment of officials from regional agencies to combat corruption. This recruitment uses an open selection method called the job auction. This method allows the civil service agency to hold an open selection for vacant positions in the regency/municipality areas to be filled with civil servants in that city or surrounding areas within the same province. The selection process is carried out by a selection committee consisting of local government and non-regional government elements such as academics and community leaders. Selection components, namely managerial competence, psychology, and program presentation, solve problems according to the position. The selection results are submitted to the regional head to be elected.

\footnotetext{
${ }^{2}$ Interview with the secretary of the Regional Civil Service Agency (BKD) Batang Regency, 27 November 2020.
} 


\section{References}

[1] KPK, "Statistik TPK Berdasarkan Profesi/Jabatan," 2021.

[2] A. A. Purbaya, "Bupati Klaten Divonis 11 Tahun Bui Atas Kasus Suap dan Gratifikasi," Detik News, 2017.

[3] N. Nurdin, "Ganjar Tetap Usung Visi 'Mboten Korupsi lan Mboten Ngapusi,"” Kompas.com, 2018.

[4] F. A. Permatasari, "The Effect of Prefessional Commitment, Integrity, Objectivity, Competence, and Professional Behavior on Auditor Performance (Empirical Study at the Inspectorate of Bali Province)," E-Journal Universitas Pendidikan Ganesha, vol. 4, no. 1, 2016.

[5] N. E. Kirana, "The Effect of Independence, Integrity, Objectivity, and Confidentially on Auditor Performance at the Inspection Office of BRI Bank Yogyakarta," E-Journal Universitas Negeri Yogyakarta, 2016.

[6] N. S. Karhi, "Beberapa Catatan Tentang Good Governance," Jurnal administrasi dan Pembangunan, vol. 1, no. 2, 1997.

[7] M. Mahfud, Ketika Gudang Kehabisan Teori Ekonomi dalam Pemerintahan Yang Bersih. Yogyakarta: UII Press, 2000.

[8] M. Toha, "Transparansi dan Pertanggungjawaban Publik Terhadap Tindakan Pemerintah," 1999.

[9] UNDP, Governance for Sustainable Development, Policy Documents. New York: United Nations Development Programme, 1997.

[10] W. N. Dunn and K. R. Popper, "Policy Analysis and Applied Social Science," The Science of Public Policy Essential Readings in Policy Sciences, pp. 29-30, 1999.

[11] W. N. Dunn, Public policy analysis. New York: Routledge, 2015.

[12] B. N. Arief, Tujuan dan pedoman pemidanaan: perspektif pembaharuan hukum pidana dan perbandingan beberapa negara. Semarang: Pustaka Magister, 2011. 